\title{
Effects of human visitation on calf growth and performance of calves fed different milk replacer feeding levels
}

\author{
N. E. Guindon, ${ }^{*}$ N. T. Antaya, ${ }^{*}$ R. G. Cabral, ${ }^{* 1}$ N. L. Whitehouse, ${ }^{*}$ T. J. Earleywine, $\dagger$ and P. S. Erickson ${ }^{* 2}$ \\ *Department of Biological Sciences, University of New Hampshire, Durham 03824 \\ †Land O'Lakes Animal Milk Products, Cottage Grove, WI 53527
}

\section{ABSTRACT}

Twenty-eight newborn Holstein heifer calves from the university herd and 8 newborn Holstein heifer calves from a commercial herd were blocked by birth and herd into 1 of 4 treatments: conventional [20\% crude protein (CP), $20 \%$ fat] milk replacer (MR; treatment C) with (1) or without (0) human visitation, or a higher plane of MR nutrition (28\% CP, $20 \%$ fat) regimen (treatment A) with (1) or (0) without human visitation. Calves on $\mathrm{C}$ MR treatments received $454 \mathrm{~g}$ of $\mathrm{MR}$ from d 2 to 41. Calves on A MR received $916 \mathrm{~g}$ of MR from d 2 to 8 and $1134 \mathrm{~g}$ of MR from d 9 to 41. Visitation with calves occurred at 1030 and $1430 \mathrm{~h}$ daily from d 1 to 56 and comprised verbal stimulation and stirring of starter grain. An opaque curtain divided the calf nursery, with calves in the front half assigned to visitation treatments and those in the rear half not assigned to visitation treatments. Calves were fed their MR treatment until d 43 (preweaning), after which all calves received half of their allotment of MR until d 49 (weaning). Calves were tracked for the next week until d 56 (postweaning). Starter grain and MR intakes were measured daily along with weekly body weight and skeletal measurements. One half of the calves on each treatment had blood samples taken via jugular venipuncture on d 41 (preweaning), 43, 45, 47, 49, and 51 (postweaning) to evaluate blood glucose, urea, nonesterified fatty acids, and cortisol concentrations. During the preweaning and weaning phases, calves on A0 and A1 treatments consumed more MR, less starter, and weighed more than the $\mathrm{C} 0$ and $\mathrm{C} 1$ calves. Calves on $\mathrm{A} 0$ and $\mathrm{A} 1$ had greater average daily gain (ADG), hip and withers gain, were taller at the hip, and had larger girths during the preweaning phase. Overall, body weight, withers and hip heights, and heart girths were greater in $\mathrm{A} 0$ and $\mathrm{A} 1$ calves during the weaning week. Efficiency of utilization of estimated metaboliz-

Received April 28, 2015.

Accepted August 29, 2015.

${ }^{1}$ Present address: Famo Feeds, Freeport, MN 56331.

${ }^{2}$ Corresponding author: peter.erickson@unh.edu able energy (ME) intake (ADG/ME) were similar. Glucose and nonesterified fatty acids concentrations were greater in visited calves preweaning. An interaction for glucose was observed during weaning, with A1 calves having the highest concentration and $\mathrm{A} 0$ calves having the lowest concentrations during weaning. Cortisol tended to be higher in visited calves during weaning. Postweaning, calves formerly fed A0 and A1 treatments had lower blood glucose and tended to have higher urea and cortisol concentrations than $\mathrm{C} 0$ and $\mathrm{C} 1$ treatments. The higher plane of nutrition fed calves tended to have higher cortisol concentrations indicating that they experienced more stress due to the removal of MR more than calves fed conventionally. Calves fed the higher plane of MR nutrition consumed more dry matter, $\mathrm{ME}$, and water weighed more, had a greater ADG, and were taller than calves fed the conventional MR. These calves were more efficient (ADG/dry matter intake) when expressed on a dry matter basis, but had similar efficiency when expressed on an ME basis (ADG/ME). Visiting calves did little to reduce the stress of weaning when calves are fed the higher plane of nutrition MR feeding regimen.

Key words: calf-human interaction, higher plane of milk replacer nutrition, starter, water intake

\section{INTRODUCTION}

Growing replacement dairy heifers to breeding height and weight within 12 to 14 mo of birth is crucial for maximizing the return on the investment of heifer raising. Feeding preweaned calves large $[>0.7 \mathrm{~kg}$ of milk replacer (MR) DM] or ad libitum amounts of MR has produced positive results in young calf growth (Cowles et al., 2006; Hill et al., 2013). Studies have reported gains $50 \%$ greater in calves fed ad libitum milk compared with limit-fed calves (Appleby et al., 2001; Jasper and Weary, 2002). Every $1 \mathrm{~kg}$ of additional ADG in calves during the preweaning period resulted in 1,113 $\mathrm{kg}$ more milk during their first lactation (Soberon et al., 2012).

Intensified (or accelerated) MR are formulated with a higher level of CP (26-28\% DM) than conventional MR 
(20-22\% DM) and fed at a higher rate than conventional MR ( $>0.7$ vs. $<0.6 \mathrm{~kg} / \mathrm{d}$ of DM). Raeth-Knight et al. (2009) observed a doubling of BW by 8 wk of age in calves fed a high-protein, low-fat MR (28\% CP, $16 \%$ fat). In that experiment, calves were fed the MR at either low solids (12.5\%) or high solids (16.7\%) until 6 wk of age; this feeding regimen is designed to maximize structural growth. Cowles et al. (2006) observed a pause in ADG in calves fed on the intensified program during weaning compared with the conventionally fed calves. In that experiment, calves were weaned beginning on d 42 and concluding on d 49 of life by only feeding half of the MR powder at the morning feeding. Postweaning, no differences were noted in ADG among treatments; this was due to the decrease in starter grain intake seen before and during weaning in calves fed an intensified program. Preweaning starter intakes were less than half of what calves fed conventional MR were eating (Cowles et al., 2006; Raeth-Knight et al., 2009). Weaning can be accomplished in several ways, including removing one of the feedings per day or removing feedings abruptly. Sweeney et al. (2010) observed BW loss in calves fed upwards of $12 \mathrm{~kg}$ of milk/d and weaned abruptly compared with calves weaned gradually. Hill et al. (2010) observed reduced DM and OM digestibility in the immediate $3 \mathrm{~d}$ postweaning with calves fed an intensified MR program. These results (Hill et al., 2010) support the results of Terre et al. (2006b), who observed reduced urinary excretion of purine derivatives from calves fed an intensified program. This same research group (Terre et al., 2007) observed reduced apparent digestibility of $\mathrm{DM}, \mathrm{OM}, \mathrm{NDF}$, and $\mathrm{CP}$ the week after weaning in calves formerly fed an intensified MR regimen. Therefore, rumen development is likely limited in calves fed an intensified program. However, Davidson et al. (2013) found no differences in rumen papillae development by $84 \mathrm{~d}$ of age in calves fed either a control MR (20\% CP, $20 \%$ fat) compared with calves fed an intensified MR feeding program (28\% CP, $20 \%$ fat).

Behavioral studies provide some insight to losses in growth during the weaning period. When raised with a companion of the same age, calves were less stressed and showed no negative responses to being weaned compared with calves raised alone. The calves raised separately ate less grain and were more stressed during weaning (Chua et al., 2002). When raised with a companion heifer of the same age and an older weaned heifer, improved results were seen in calf performance before and during weaning. Calves that had an older companion began eating starter at an earlier age, consumed more starter throughout the experiment, and showed few signs of stress during weaning compared with calves raised singly. These data indicate the importance of social learning for calves (De Paula Vieira et al., 2012). Recently, Jensen et al. (2015) showed that pair-housed calves fed $9 \mathrm{~L}$ of milk and allowed to play consumed more concentrate than individually housed calves fed $9 \mathrm{~L}$ of milk, suggesting that social interaction will improve starter intake. These calves (pair-housed and fed $9 \mathrm{~L}$ of milk/d) also had greater ADG than calves fed $5 \mathrm{~L}$ of milk/d that were housed individually or in pairs, or those fed $9 \mathrm{~L}$ of milk but housed individually. These data indicate that social interaction can enhance growth and starter intake in calves fed a high plane of nutrition MR and possibly decrease stress during weaning.

We hypothesized that additional human attention throughout the day, by way of visitation, auditory stimulation of the calf and handling the starter grain, would help minimize weaning stress and maximize calf growth for calves fed a higher plane of nutrition feeding program. The objectives of our experiment were to compare the performance of calves fed different milk replacer feeding programs and to determine if human interaction improved performance and reduced weaning stress in calves.

\section{MATERIALS AND METHODS}

\section{Calves, Diets and Treatments}

This experiment was reviewed and approved by the University of New Hampshire Institutional Animal Care and Use Committee (protocol \#120106). Thirtysix Holstein heifer calves from 2 New Hampshire farms (28 calves from the University of New Hampshire herd and 8 from a commercial herd) were randomly assigned at birth and by herd to 1 of 4 treatments in a $2 \times 2$ factorial arrangement of treatments in a randomized complete block design. The treatments were (1) a nonmedicated, conventional MR (20\% CP, $20 \%$ fat) with (C1) or without (C0) visits or (2) high-protein MR (28\% CP, 20\% fat) with (A1) or without (A0) visits. Both MR products were provided by Land O'Lakes Animal Milk Products (Shoreview, MN)

Calves from the university herd were removed from their dams immediately after birth and transferred to an individual calf stall $(1 \times 2.15 \mathrm{~m})$ in a naturally ventilated, enclosed calf room. Additional cross-ventilation was added with $50.8-\mathrm{cm}$ window-mounted box fans, as barn curtain dividers had some effect of natural ventilation. Dry shavings were used on top of indwelling stall mattresses. A lacteal-based colostrum replacer $(1.9 \mathrm{~L}$; Land O'Lakes Animal Milk Products) was fed within $1 \mathrm{~h}$ of birth and again between 6 and $8 \mathrm{~h}$ after birth. 
Calves from the commercial dairy were removed from their dam immediately at birth and placed in a newborn calf pen until transported to the university facility. They were fed their first feeding of colostrum (2 L) at their home farm, and then transferred $(24 \mathrm{~km})$ to the university farm in a deeply bedded livestock transport crate to the university on the day of birth before the second feeding of colostrum replacer. Calves were fed colostrum replacer (university) or colostrum (first feeding, commercial farm) with a nipple bottle. All calves were vaccinated for Escherichia coli (Bar-Guard 99, Boehringer Ingelheim, Ingelheim, Germany) and Rota Corona Virus (Calf Guard, Pfizer Animal Health, Exton, PA) in accordance to university farm protocol.

Calves were given free choice nonmedicated coarse starter grain (Table 1; Kent Nutrition, Bow, NH) and water starting at $2 \mathrm{~d}$ of age and continuing for the duration of study. Starter grain was collected and replaced daily at $1700 \mathrm{~h}$. The starter grain was comprised of steam-flaked corn, crimped oats, molasses, and a protein pellet. The amount of grain offered each day was regulated by the previous day intake. When refusals weighed $<227.5 \mathrm{~g}$, the next feeding was raised by 227.5 $\mathrm{g}$ to ensure constant access to grain. Fresh water was replaced twice daily at 0700 and $1700 \mathrm{~h}$. Water refusals and fresh water offered was weighed and recorded at each feeding.

Calves on treatments $\mathrm{C} 0$ and $\mathrm{C} 1$ were fed $227 \mathrm{~g}$ of 20:20 (CP:fat) MR reconstituted to $12 \%$ DM twice daily $(0700$ and $1700 \mathrm{~h})$ from $\mathrm{d} 2$ to $41(1.89 \mathrm{~L}$ twice daily). Calves on A0 and A1 were fed $408 \mathrm{~g}$ of a 28:20 MR reconstituted to $17 \%$ DM twice daily (0700 and $1700 \mathrm{~h}$ ) for $\mathrm{d} 2$ to 8 (2.4 L twice daily) and then raised to $567 \mathrm{~g}$ reconstituted to $17 \% \mathrm{DM}$ from d 9 to 41 (3.33 $\mathrm{L}$ twice daily). On d 42 to 48 , calves on both treatments

Table 1. Nutrient composition of milk replacers and calf starter grain (DM basis)

\begin{tabular}{lccc}
\hline Item & $\begin{array}{c}\text { Control } \\
\mathrm{MR}^{1}\end{array}$ & $\begin{array}{c}\text { High plane } \\
\text { of nutrition } \mathrm{MR}^{2}\end{array}$ & $\begin{array}{c}\text { Starter } \\
\text { grain }\end{array}$ \\
\hline DM, \% & 95.1 & 95.0 & 85.3 \\
CP, \% & 21.0 & 28.6 & 22.8 \\
NDF, \% & - & - & 23.4 \\
ADF, \% & - & 19.5 & 9.7 \\
Fat, \% & 20.1 & 0.8 & 3.9 \\
Ca, \% & 0.8 & 0.9 & 0.8 \\
P, \% & 0.9 & 0.14 & 0.7 \\
Mg, \% & 0.15 & 2.4 & 0.4 \\
K, \% & 2.7 & 0.4 & 1.6 \\
S, \% & 0.3 & & 0.3 \\
\hline
\end{tabular}

${ }^{1}$ Milk replacer used in $\mathrm{C} 0$ and $\mathrm{C} 1$ treatments; $\mathrm{C} 0=$ control milk replacer, no visits; $\mathrm{C} 1=$ control milk replacer + visits.

${ }^{2}$ Milk replacer used in A0 and A1 treatments; A0 = high plane of nutrition milk replacer, no visits; A1 = high plane of nutrition milk replacer + visits. were fed once daily at $1700 \mathrm{~h}$. Calves were fed MR and water in pails. On d 49, all milk feeding ceased.

\section{Feed Analysis}

Composites were made of each dry feed and sent to Analab (Fulton, IL) using official methodology (AOAC International, 2002). Samples of starter grain and MR were analyzed for DM (method 935.29), CP (method 976.06), NDF (method 2002.04), ADF (method 973.18), $\mathrm{Ca}, \mathrm{P}, \mathrm{Mg}, \mathrm{Na}, \mathrm{K}$ (method 985.01), and S (method 923.01). In the MR, FA were determined by saponification with $\mathrm{KOH}$ in ethyl alcohol. The FA were liberated from the soaps with $\mathrm{HCl}$ and extracted with petroleum ether (AOAC International, 1995). Metabolizable energy was calculated by overriding data in the NRC dairy evaluation program (NRC, 2001) with the values from these analyses for MR and starter grain. Chemical analyses of MR and starter grain are shown in Table 1. Metabolizable energy for starter grain, conventional MR, and high-protein MR were estimated to be 3.28, 4.77 , and $4.87 \mathrm{Mcal} / \mathrm{kg}$, respectively.

\section{Visitation Schedule}

To control human traffic through the calf barn, a lock was installed on the barn door. All entries were authorized and documented by researchers. Other than research personnel, entries were limited to the barn manager and staff veterinarian. Calves on treatments $\mathrm{A} 0$ and $\mathrm{C} 0$ were housed in half of the barn behind an industrial grade opaque plastic floor-to-ceiling curtain. This was done to minimize the visual stimulation of the visitation treatments on the behavior of the $\mathrm{C} 0$ and $\mathrm{A} 0$ calves.

Calves on A1 and C1 treatments were housed in the front half of the barn in the proximity of the entry door and were visited daily at 1030 and $1400 \mathrm{~h}$ from d 1 to 56 of the experiment. At this time, a researcher entered the calf barn and approached each calf one at a time. The researcher reached into the bucket containing calf starter and stirred it by hand while calling to the calf. If the calf stood and approached the buckets, starter was held in front of their nose and then placed in their mouth. Approximately $30 \mathrm{~s}$ were spent with each calf before moving to the next. After each calf was visited, the researcher left the barn and locked the barn door again. Calves ( $\mathrm{C} 0$ and $\mathrm{A} 0)$ received some indirect visitation, as they were able to hear the researcher through the curtain. Therefore, the experiment could not exclude the effect of auditory effects, the study was designed to test the effect of visual, auditory, and individual attention given to each visited calf. 


\section{Measurements and Sampling}

Calves were weighed immediately after birth, and then weekly thereafter on a platform scale (A and A Scales LLC, VS-2000, Prospect Park, NJ). Starting at wk 1 , withers and hip heights were measured with a sliding scale height stick with a bubble level, and heart girth was measured with a weigh tape. Calves were measured on an individual basis by birth date during evening feeding and cleaning.

Five calves on each treatment were randomly selected for blood sampling. This sampling occurred every other day starting before weaning (d 41) and continuing through the weaning week (d 43, 45, 47, and 49), and after weaning (d 51). Blood samples were taken at $1030 \mathrm{~h}$ after scheduled visits. Blood was collected via jugular venipuncture using 5 -mL evacuated tubes with anticoagulant and 22-gauge needles. Blood was centrifuged immediately after collection at 3,300 $\times g$ for $20 \mathrm{~min}$ at $4^{\circ} \mathrm{C}$. Supernatants were divided into 2 aliquots and stored at $-4^{\circ} \mathrm{C}$ for later analysis. Glucose was analyzed with Glucose Autokit and NEFA were analyzed with a HR Series NEFA-HR (2) (Wako Diagnostics, Richmond, VA). Cortisol was analyzed with a Cortisol Enzyme Immunoassay Kit (Arbor Assays, Ann Arbor, MI). The limited number of calves used for blood sampling in this experiment could potentially cause large variation in metabolite analyses.

\section{Statistical Analysis}

Weekly DMI, ME intake, ADG for BW and skeletal measurements, ADG/DMI, ADG/ME intake, and blood measurements during the weaning week were analyzed as a randomized complete block design using repeated measures determined in the MIXED procedure of SAS (Version 9.3; SAS Institute Inc., Cary, NC) according to the following model:

$$
\begin{aligned}
\mathrm{Y}_{\mathrm{ijk}}= & \mu+\mathrm{B}_{\mathrm{i}}+\mathrm{MR}_{\mathrm{j}}+\mathrm{V}_{\mathrm{k}}+\mathrm{MRV}_{\mathrm{jk}} \\
& +\mathrm{W}_{\mathrm{jkl}}+\mathrm{kC}_{\mathrm{ijkl}}+\mathrm{E}_{\mathrm{ijklm}},
\end{aligned}
$$

where $\mathrm{Y}=$ the dependent variable; $\mu=$ the overall mean; $\mathrm{B}_{\mathrm{i}}=$ the random effect of block $\mathrm{i}(\mathrm{i}=1, \ldots, 9)$; $\mathrm{MR}_{\mathrm{j}}=$ the effect of $\mathrm{MR}$ type, the jth treatment (either conventional or high protein); $\mathrm{V}_{\mathrm{k}}=\mathrm{kth}$ visits (0 or 2); $\mathrm{MRV}_{\mathrm{jk}}=$ the interaction between MR type and visits; $\mathrm{W}_{\mathrm{jkl}}=$ the effect of week; $\mathrm{kC}_{\mathrm{ijkl}}=$ the value of the covariate variable for the lth calf, of the ith block, of jth visits, $\mathrm{kth} \mathrm{MR}$ type $(1=1, \ldots, 36)$; and $\mathrm{E}_{\mathrm{ijk} k \mathrm{~m}}=$ the residual error $\sim \mathrm{Ne}\left(0, \sigma_{\mathrm{e}}^{2}\right)$. and $\sigma^{2}$ is the population standard deviation.
Blood measurements on d 41 and 51 were analyzed as a randomized complete block design using the MIXED procedure of SAS according to the following model:

$$
Y_{i j}=\mu+B_{i}+M R_{j}+V_{k}+M_{R} V_{j k}+\mathrm{kC}_{i j k}+E_{i j l},
$$

where $\mathrm{Y}=$ the dependent variable; $\mu=$ the overall mean; $\mathrm{B}_{\mathrm{i}}=$ the random effect of block $\mathrm{i}(\mathrm{i}=1, \ldots, 9)$; $\mathrm{MR}_{\mathrm{j}}=$ the effect of MR type, the jth treatment (either conventional or high protein); $\mathrm{V}_{\mathrm{k}}=\mathrm{kth}$ visits $(0$ or 2$)$; $\mathrm{MRV}_{\mathrm{jk}}=$ the interaction between MR type and visits; $\mathrm{kC}_{\mathrm{ijk}}$ is the value of the covariate variable for the lth calf, of the ith block, of jth visits, kth MR type $(l=1$, $\ldots, 36)$; and $\mathrm{E}_{\mathrm{ijl}}=$ the residual error $\sim \mathrm{Ne}\left(0, \sigma_{\mathrm{e}}^{2}\right)$.

Calves from the second farm were randomly assigned to treatments within 2 blocks specific for that farm. Data were run through 4 covariance structures: unstructured, compound symmetry, Toeplitz, and firstorder autoregressive. For first-order autoregressive, calf was considered random. The covariance structure with the smaller Bayesian information criterion value was selected. Initial BW was used as a covariate for all intake and growth calculations. Significance was determined at a probability of $P<0.05$. Trends were defined as: $0.05 \leq P \leq 0.10$.

\section{RESULTS}

\section{Preweaning Period}

Data collected during the preweaning period (wk 1-6) are shown in Table 2. As expected, calves on A0 and $\mathrm{A} 1$ treatments consumed more MR and less starter grain than $\mathrm{C} 0$ and $\mathrm{C} 1$ calves. Dry matter intake and $\mathrm{ME}$ intake were greater for calves fed A0 or A1. Calves fed $\mathrm{A} 0$ and $\mathrm{A} 1$ consumed more water than calves fed conventional MR. Calves fed the higher plane of nutrition MR regimen had higher ADG, weighed more, and were more efficient. Although total DMI and feed efficiency were greater for calves on the higher plane of nutrition program, starter grain intake was about $50 \%$ less than conventionally fed calves. When expressed as ADG/Mcal, no differences were noted among treatments. Average BW, withers height, withers height gain, hip height, hip height gain, and heart girth were greater for calves fed the higher plane of nutrition MR feeding program (A0, A1) than calves fed conventionally $(\mathrm{C} 0, \mathrm{C} 1)$. Visiting calves had no effect on hip, girth or weight gains, DMI, water intake, starter intake, or overall feed efficiency. Withers height gain was reduced in visited calves compared with nonvisited calves. 


\section{Weaning Week}

Intake and growth measurements taken during the weaning week are presented in Table 3. Calves fed on the higher plane of nutrition MR program (A0, A1) consumed more MR and less starter grain than calves fed conventional MR. However, no differences were observed in DMI, ME intake, or ADG across treatments. Average BW during the weaning week remained elevated for calves fed A0 or A1 compared with calves on $\mathrm{C} 0$ and $\mathrm{C} 1$ treatments. Feed efficiency expressed as either ADG/DMI or ADG/Mcal was similar across treatments. Average withers height, hip height, and girth were greater for calves on the A0 and A1 treatments than calves on the $\mathrm{C} 0$ or $\mathrm{C} 1$ treatments. An interaction for withers height gain was noted, with A1 calves having the greatest withers height gain whereas $\mathrm{C} 1$ calves had the lowest withers height gain. Other skeletal growth gains were similar across treatments.

Blood measurement data before (d 41), during (d 43, 45, 47, and 49), and at after weaning (d 51) are presented in Table 4. On d 41, no differences were present among treatments for urea or cortisol concentration; however, glucose and NEFA concentrations were elevated for calves that were visited. These effects did not continue during weaning (d 43,45, 47, or 49) or postweaning (d 51). An interaction for glucose was noted during the weaning week, with A1 calves having the highest glucose concentrations whereas A0 calves had the lowest concentration of glucose. During the weaning phase, cortisol tended to be elevated in visited calves. No effects of treatment on urea or NEFA concentrations were observed; however, an interaction occurred where A1 calves had the lowest cortisol concentration whereas cortisol increased in $\mathrm{C} 1$ calves. Postweaning (d 51 ), no effects of visitation were observed on any blood measurement. However, calves formerly on the A0 and A1 treatments had lower glucose, but tended to have higher urea and cortisol concentrations.

\section{Postweaning Week}

During the postweaning period (Table 5), DMI and ME intake (starter) tended to be lower $(P=0.08)$ for calves on the $\mathrm{A} 0$ and $\mathrm{A} 1$ treatments. No differences were noted for ADG, water intake, ADG/DMI, ADG/ Mcal, and hip or girth gains. However, BW remained greater $(P=0.002)$ for calves formerly fed the higher plane of nutrition MR program (A0, A1) than calves formerly fed the conventional program. Calves formerly fed the higher plane of nutrition MR program (A0, A1) were taller at the withers and hip and had larger girths than calves formerly on the conventional feeding program.

\section{Overall Experiment}

Over the entire experiment, calves fed A0 and A1 consumed more DM, ME, and water than calves on

Table 2. Preweaning intake and growth data (d1-41)

\begin{tabular}{|c|c|c|c|c|c|c|c|c|}
\hline Item & \multicolumn{4}{|c|}{ Treatment $^{1}$} & SEM & \multicolumn{3}{|c|}{$P$-value } \\
\hline Milk replacer intake, $\mathrm{g} / \mathrm{d}$ & 453 & 453 & 1098 & 1090 & 5.4 & 0.39 & $<0.001$ & 0.51 \\
\hline Starter intake, g/d & 494 & 404 & 235 & 238 & 58.4 & 0.46 & 0.006 & 0.43 \\
\hline DMI, g/d & 928 & 860 & 1274 & 1294 & 59.4 & 0.66 & 0.007 & 0.46 \\
\hline $\mathrm{MEI},{ }^{5} \mathrm{Mcal} / \mathrm{d}$ & 3.36 & 3.01 & 5.72 & 5.61 & 0.15 & 0.11 & $<0.001$ & 0.39 \\
\hline $\mathrm{ADG}, \mathrm{g}$ & 412 & 404 & 640 & 617 & 88 & 0.85 & 0.01 & 0.93 \\
\hline ADG/DMI & 0.41 & 0.39 & 0.53 & 0.49 & 0.04 & 0.35 & 0.007 & 0.90 \\
\hline ADG/MEI, g/Mcal & 108.2 & 113.2 & 113.2 & 108.0 & 12.6 & 0.99 & 1.00 & 0.70 \\
\hline Withers, $\mathrm{cm}$ & 80.3 & 81.0 & 81.6 & 81.4 & 1.00 & 0.76 & 0.35 & 0.66 \\
\hline Withers gain, $\mathrm{cm} / \mathrm{d}$ & 0.17 & 0.14 & 0.23 & 0.21 & 0.01 & 0.04 & $<0.001$ & 0.66 \\
\hline Hip, cm & 83.9 & 84.0 & 86.2 & 86.0 & 0.79 & 0.94 & 0.008 & 0.82 \\
\hline Hip gain, $\mathrm{cm} / \mathrm{d}$ & 0.17 & 0.16 & 0.21 & 0.23 & 0.02 & 0.90 & 0.01 & 0.47 \\
\hline
\end{tabular}


Table 3. Weaning period (d 42-49) intake and growth data

\begin{tabular}{|c|c|c|c|c|c|c|c|c|}
\hline Measurement & \multicolumn{4}{|c|}{ Treatment $^{1}$} & SEM & \multicolumn{3}{|c|}{$P$-value } \\
\hline Starter intake., g/d & 1,804 & 1,639 & 1,211 & 1,215 & 166 & 0.60 & 0.003 & 0.60 \\
\hline DMI, g/d & 2,031 & 1,866 & 1,776 & 1,782 & 167 & 0.60 & 0.27 & 0.60 \\
\hline $\mathrm{MEI},{ }^{5} \mathrm{Mcal} / \mathrm{d}$ & 6.99 & 6.45 & 6.72 & 6.74 & 0.55 & 0.61 & 0.99 & 0.60 \\
\hline Water, L/d & 4.5 & 3.5 & 3.7 & 4.1 & 0.44 & 0.91 & 0.64 & 0.16 \\
\hline ADG/DMI & 0.45 & 0.44 & 0.34 & 0.51 & 0.08 & 0.28 & 0.81 & 0.24 \\
\hline ADG/MEI, g/Mcal & 129.8 & 127.1 & 89.6 & 134.5 & 21.1 & 0.30 & 0.42 & 0.24 \\
\hline Withers, cm & 86.3 & 86.3 & 89.4 & 89.6 & 0.63 & 0.80 & $<0.001$ & 0.85 \\
\hline Withers gain, $\mathrm{cm} / \mathrm{d}$ & $0.21^{\mathrm{a}}$ & $0.16^{\mathrm{b}}$ & $0.18^{\mathrm{b}}$ & $0.32^{\mathrm{a}}$ & 0.05 & 0.42 & 0.18 & 0.05 \\
\hline Hip cm & 88.1 & 88.6 & 91.2 & 91.4 & 0.52 & 0.51 & 0.001 & 0.83 \\
\hline Hip gain, $\mathrm{cm} / \mathrm{d}$ & 0.12 & 0.18 & 0.13 & 0.11 & 0.05 & 0.68 & 0.50 & 0.42 \\
\hline Girth, cm & 96.9 & 96.3 & 100.5 & 100.7 & 1.23 & 0.84 & 0.002 & 0.76 \\
\hline
\end{tabular}

${ }^{\mathrm{a}, \mathrm{b}}$ Means with different superscripts differ $(P=0.05)$.

${ }^{1}$ Treatment $\mathrm{C} 0=$ control milk replacer, no visits; $\mathrm{C} 1=$ control milk replacer + visits; $\mathrm{A} 0=$ high plane of nutrition milk replacer, no visits; A1 $=$ high plane of nutrition milk replacer + visits.

${ }^{2} \mathrm{Vis}=$ visitation of calves at 1030 and $1430 \mathrm{~h}$.

${ }^{3} \mathrm{MR}=$ milk replacer type, conventional or accelerated.

${ }^{4}$ Int $=$ interaction between visits and milk replacer type.

${ }^{5}$ Estimatation of metabolizable energy intake (MEI), Mcal/d.

the $\mathrm{C} 0$ and $\mathrm{C} 1$ treatments, resulting in greater $\mathrm{ADG}$, final BW, and height as well as a greater girth (Table 6). Calves fed the A0 and A1 treatments were more efficient when expressed as ADG/DMI; however, this was not the case when expressed as ADG/ME intake. Withers gain was greater for A0 and A1 calves; hip gains and girth gains were similar over the entire study.
There was an interaction for $\mathrm{C} 1$ calves to have a lesser withers height gain than the other calves.

\section{DISCUSSION}

Our results support research by Cowles et al. (2006) and Raeth-Knight et al. (2009), who found that dur-

Table 4. Blood measurements for calves fed either conventional or accelerated milk replacer with or without visiting twice daily

\begin{tabular}{|c|c|c|c|c|c|c|c|c|c|}
\hline \multirow[b]{2}{*}{ Day $^{1}$} & \multirow[b]{2}{*}{ Measurement } & \multicolumn{4}{|c|}{ Treatment $^{2}$} & \multirow[b]{2}{*}{ SEM } & \multicolumn{3}{|c|}{$P$-value } \\
\hline & & $\mathrm{C} 0$ & $\mathrm{C} 1$ & $\mathrm{~A} 0$ & $\mathrm{~A} 1$ & & $\mathrm{Vis}^{3}$ & $\mathrm{MR}^{4}$ & $\operatorname{Int}^{5}$ \\
\hline \multirow[t]{4}{*}{41} & Glucose, mg/dL & 89.7 & 107.7 & 87.7 & 120.6 & 9.3 & 0.02 & 0.54 & 0.44 \\
\hline & Urea, mg/dL & 21.2 & 26.1 & 22.3 & 22.1 & 1.6 & 0.17 & 0.35 & 0.14 \\
\hline & NEFA, $\mu \mathrm{Eq} / \mathrm{L}$ & 124.8 & 249.1 & 223.6 & 267.8 & 37.9 & 0.04 & 0.13 & 0.29 \\
\hline & Cortisol, $\mathrm{ng} / \mathrm{mL}$ & 21.4 & 27.7 & 38.5 & 29.7 & 5.70 & 0.82 & 0.11 & 0.20 \\
\hline \multirow[t]{4}{*}{$43-49$} & Glucose, $\mathrm{mg} / \mathrm{dL}$ & $84.6^{\mathrm{x}}$ & $78.5^{\mathrm{xy}}$ & $73.1^{\mathrm{b}, \mathrm{y}}$ & $88.5^{\mathrm{a}, \mathrm{x}}$ & 2.70 & 0.29 & 0.85 & 0.03 \\
\hline & Urea, mg/dL & 25.0 & 26.6 & 27.5 & 25.3 & 1.20 & 0.80 & 0.63 & 0.12 \\
\hline & NEFA, $\mu \mathrm{Eq} / \mathrm{L}$ & 82.8 & 139.3 & 139.1 & 158.0 & 30.2 & 0.21 & 0.21 & 0.52 \\
\hline & Cortisol, $\mathrm{ng} / \mathrm{mL}$ & 16.4 & 21.5 & 15.0 & 20.3 & 3.3 & 0.10 & 0.66 & 0.97 \\
\hline \multirow[t]{4}{*}{51} & Glucose, mg/dL & 88.6 & 95.4 & 70.8 & 83.2 & 7.0 & 0.20 & 0.04 & 0.68 \\
\hline & Urea, mg/dL & 25.7 & 27.5 & 28.1 & 30.4 & 1.4 & 0.15 & 0.08 & 0.84 \\
\hline & $\mathrm{NEFA}, \mu \mathrm{Eq} / \mathrm{L}$ & 82.3 & 100.4 & 116.9 & 113.4 & 21.5 & 0.73 & 0.27 & 0.61 \\
\hline & Cortisol, $\mathrm{ng} / \mathrm{mL}$ & 21.6 & 18.9 & 26.7 & 31.1 & 5.5 & 0.86 & 0.10 & 0.47 \\
\hline
\end{tabular}

\footnotetext{
${ }^{\mathrm{a}, \mathrm{b}}$ Means with different superscripts differ $(P=0.03)$.

${ }^{\mathrm{x}, \mathrm{y}}$ Means with different superscripts differ $(P \leq 0.10)$.

${ }^{1}$ Day of age, $41=\mathrm{d}$ immediately preweaning; 43,45,47,49 = every other day during weaning week; $51=2 \mathrm{~d}$ postweaning.

${ }^{2}$ Treatment $\mathrm{C} 0=$ control milk replacer, no visits; $\mathrm{C} 1=$ control milk replacer + visits; $\mathrm{A} 0=$ high plane of nutrition milk replacer, no visits; A1 $=$ high plane of nutrition milk replacer + visits.

${ }^{3} \mathrm{Vis}=$ visitation of calves at 1030 and $1430 \mathrm{~h}$.

${ }^{4} \mathrm{MR}=$ milk replacer type, conventional or accelerated

${ }^{5} \mathrm{Int}=$ interaction between visits and milk replacer type.
} 
Table 5. Postweaning (d 50-56) intake and growth data

\begin{tabular}{|c|c|c|c|c|c|c|c|c|}
\hline Measurement & \multicolumn{4}{|c|}{ Treatment $^{1}$} & SEM & \multicolumn{3}{|c|}{$P$-value } \\
\hline DMI (starter), $\mathrm{kg} / \mathrm{d}$ & 2.5 & 2.4 & 2.0 & 2.3 & 0.20 & 0.48 & 0.08 & 0.24 \\
\hline $\mathrm{ADG}, \mathrm{kg}$ & 1.1 & 1.2 & 1.0 & 1.0 & 0.13 & 0.85 & 0.39 & 0.85 \\
\hline Water intake, L/d & 7.6 & 6.8 & 7.4 & 6.9 & 0.55 & 0.18 & 0.92 & 0.76 \\
\hline $\mathrm{ADG} / \mathrm{DMI}$ & 0.46 & 0.50 & 0.54 & 0.44 & 0.07 & 0.68 & 0.87 & 0.32 \\
\hline Hip gain, $\mathrm{cm} / \mathrm{d}$ & 0.29 & 0.16 & 0.12 & 0.19 & 0.07 & 0.72 & 0.28 & 0.16 \\
\hline Girth gain, $\mathrm{cm} / \mathrm{d}$ & 0.27 & 0.28 & 0.22 & 0.22 & 0.11 & 0.97 & 0.63 & 0.96 \\
\hline
\end{tabular}

${ }^{\mathrm{x}, \mathrm{y}}$ Means with different superscripts tend to differ $(P<0.10)$.

${ }^{1}$ Treatment $\mathrm{C} 0=$ control milk replacer, no visits; $\mathrm{C} 1=$ control milk replacer + visits; $\mathrm{A} 0=$ high plane of nutrition milk replacer, no visits; A1 $=$ high plane of nutrition milk replacer + visits.

${ }^{2} \mathrm{Vis}=$ visitation of calves at 1030 and $1430 \mathrm{~h}$.

${ }^{3} \mathrm{MR}=$ milk replacer type, conventional or accelerated.

${ }^{4}$ Int $=$ interaction between visits and milk replacer.

${ }^{5}$ Estimatation of metabolizable energy intake (MEI), Mcal/d.

ing the preweaning period calves on accelerated MR feeding programs gained more weight and had greater skeletal growth than calves fed a conventional MR. Our calves followed this same pattern, with ADG about $50 \%$ greater for $\mathrm{A} 0$ and $\mathrm{A} 1$ calves, and withers and hip heights almost $3 \mathrm{~cm}$ taller than $\mathrm{C} 0$ and $\mathrm{C} 1$ calves during weaning.

Starter grain intakes also supported findings by Cowles et al. (2006) and Raeth-Knight et al. (2009). During the preweaning phase and during the weaning week, A0 and A1 calves only consumed half of the amount of starter grain that $\mathrm{C} 0$ and $\mathrm{C} 1$ calves ate. This is most likely due to the highly nutrient dense MR fed at a high volume fulfilling most of the nutrient requirements of the calf, leaving little desire to eat grain. Although during the postweaning phase this gap did close some, A0 and A1 calves ate about $88 \%$ of the $\mathrm{C} 0$ and $\mathrm{C} 1$ calves.

Water intake was affected by MR. Water intake overall was more than 1.6 times as high for A0 and $\mathrm{A} 1$ calves as it was for $\mathrm{C} 0$ and $\mathrm{C} 1$ calves through the preweaning period. The nutrient density was higher

Table 6. Overall performance of calves for calves fed either conventional or accelerated milk replacer with or without visiting twice daily (d $1-56)$

\begin{tabular}{|c|c|c|c|c|c|c|c|c|}
\hline Measurement & \multicolumn{4}{|c|}{ Treatment $^{1}$} & SEM & \multicolumn{3}{|c|}{$P$-value } \\
\hline DMI kg/d & 1.33 & 1.17 & 1.44 & 1.50 & 0.09 & 0.56 & 0.02 & 0.23 \\
\hline $\mathrm{ADG}, \mathrm{g} / \mathrm{d}$ & 560.5 & 527.7 & 694.6 & 705.4 & 44.3 & 0.79 & 0.001 & 0.61 \\
\hline Water intake, L/d & 2.50 & 2.03 & 3.00 & 3.07 & 0.29 & 0.46 & 0.008 & 0.33 \\
\hline Final weight, kg & 73.3 & 71.7 & 80.9 & 81.4 & 2.66 & 0.83 & 0.002 & 0.69 \\
\hline Withers gain, $\mathrm{cm} / \mathrm{d}$ & $0.19^{\mathrm{a}}$ & $0.15^{\mathrm{b}}$ & $0.21^{\mathrm{a}}$ & $0.22^{\mathrm{a}}$ & 0.02 & 0.28 & 0.002 & 0.03 \\
\hline Final hip, cm & 90.2 & 89.7 & 92.0 & 92.8 & 0.62 & 0.79 & $<0.001$ & 0.34 \\
\hline Hip gain, $\mathrm{cm} / \mathrm{d}$ & 0.18 & 0.16 & 0.18 & 0.21 & 0.02 & 0.84 & 0.12 & 0.19 \\
\hline Final girth, cm & 98.8 & 98.3 & 102.1 & 102.2 & 1.08 & 0.87 & 0.002 & 0.79 \\
\hline Girth gain, cm/d & 0.26 & 0.26 & 0.30 & 0.30 & 0.04 & 0.92 & 0.39 & 0.96 \\
\hline
\end{tabular}

${ }^{\mathrm{a}, \mathrm{b}}$ Means with different superscripts differ $(P=0.03)$.

${ }^{1}$ Treatment $\mathrm{C} 0=$ control milk replacer, no visits; $\mathrm{C} 1=$ control milk replacer + visits; $\mathrm{A} 0=$ high plane of nutrition milk replacer, no visits; A1 $=$ high plane of nutrition milk replacer + visits.

${ }^{2} \mathrm{Vis}=$ visitation of calves at 1030 and $1430 \mathrm{~h}$.

${ }^{3} \mathrm{MR}=$ milk replacer type, conventional or accelerated.

${ }^{4}$ Int $=$ interaction between visits and milk replacer.

${ }^{5}$ Estimatation of metabolizable energy intake (MEI), Mcal/d. 
in the high-protein MR (reconstituted to almost 50\% higher solids), likely causing an osmolality effect and that combined with greater tissue accretion may have driven calves to drink more free water.

A pause in growth was seen in all treatment groups during the weaning week. Leading up to weaning, ADG of the $\mathrm{C} 0$ and $\mathrm{C} 1$ calves was $65 \%$ of the $\mathrm{A} 0$ and $\mathrm{A} 1$ calves. During weaning, most likely due to lower starter intakes for $\mathrm{A} 0$ and $\mathrm{A} 1$ calves compared with the $\mathrm{C} 0$ and C1 calves, ADG was similar across treatments; this was not observed in other studies. Cowles et al. (2006) observed accelerated MR-fed calves had ADG $<20 \%$ that of conventionally fed calves during weaning. In their study, calves on the higher plane of nutrition MR consumed almost twice as much MR from wk 3 through 6 , but about one-third as much starter. In contrast, calves on A0 and A1 in the current study consumed about $200 \mathrm{~g}$ less MR powder and about $50 \mathrm{~g}$ more calf starter per day than calves on the high plane of nutrition in Cowles et al. (2006). Possibly, the stress of weaning was less pronounced in the current study due to the lower MR intakes and the higher starter intakes in the $\mathrm{A} 0$ and $\mathrm{A} 1$ treatments compared with those of Cowles et al. (2006). Sweeney et al. (2010) fed calves up to 12 $\mathrm{kg}$ of milk daily and milk solids were calculated to be $12.77 \%$; therefore, calves consumed $1,532 \mathrm{~g} / \mathrm{d}$ of milk solids. Sweeney et al. (2010) evaluated starter intake using 4 weaning methods (22 d of weaning beginning on $\mathrm{d} 19 ; 10 \mathrm{~d}$ of weaning beginning on $\mathrm{d} 31 ; 4 \mathrm{~d}$ of weaning beginning on $\mathrm{d} 37$; and abrupt weaning on $\mathrm{d}$ 41) in which milk was reduced by $0.55,1.2,3.0$, and 12 $\mathrm{kg} / \mathrm{d}$ respectively. Calves that were weaned over 10 or $22 \mathrm{~d}$ consumed about $200 \mathrm{~g} / \mathrm{d}$ more starter preweaning than calves either weaned abruptly or weaned over a 4-d period. In their study, postweaning starter intake (d 41-49) was similar for calves weaned gradually (1-1.2 $\mathrm{kg} / \mathrm{d})$ compared with calves weaned abruptly $(0.7 \mathrm{~kg} / \mathrm{d})$. The abruptly weaned calves weighed more at the end of the preweaning period then the calves weaned over 4 or $22 \mathrm{~d}$. However, the abruptly weaned calves lost $210 \mathrm{~g} / \mathrm{d}$ over the weaning period compared with the other calves. The calves on the 22 -d weaning program, although weighing the least at the end of the preweaning phase, gained over $500 \mathrm{~g} / \mathrm{d}$ over the postweaning phase. These data suggest that calves should be weaned gradually, especially when they are fed a large amount of milk. In Sweeney et al. (2010), the 10-d weaning program was the most advantageous because calves did not lose weight during the weaning phase and weighed as much as the calves weaned abruptly. The results of the current study indicated that calves fed the higher plane of nutrition MR did not experience the reduction in BW in abruptly weaned calves (Sweeney et al., 2010). Cowles et al. (2006) observed reduced ADG dur- ing the immediate postweaning phase in calves fed over $1,300 \mathrm{~g}$ of MR powder preweaning. These results were likely due to a combination of gradual weaning and consumption of about $200 \mathrm{~g}$ less MR powder and more starter intake. If calves were fed more MR, visitation may have proven to be beneficial in reducing stress and improve performance during weaning.

No difference in ADG continued postweaning. Visiting the calf and stirring the starter grain was intended to mimic the care and teaching that cows and peers appear to do for calves (Lensink et al., 2000; De Paula Vieira et al., 2012) as well as to reduce stress typically seen during and after weaning. Visitation alone did not appear to have any effects on grain intake or calf growth, except withers height gain was lower in calves that were visited. During the preweaning phase, calves did not eat any more grain when they were visited and fed conventional MR. Postweaning calves formerly on either A0 or A1 weighed more and were taller, but DMI tended to remain lower than calves fed conventionally (C0 and C1). Jensen et al. (2015) observed greater concentrate intake and greater ADG in calves that were housed in pairs and fed $9 \mathrm{~L}$ of milk/d rather than individually raised calves fed $9 \mathrm{~L}$ of milk/d; our data do not support these results. Possibly, a longer duration of visitation ( $>30 \mathrm{~s}$ ) could have resulted in improved performance in the visited calves. Also, providing a new pail of starter grain at each visit might have stimulated increased starter intake in visited calves, resulting in improved performance and less stress during the weaning period.

The results of the current study indicated that calves fed the higher plane of nutrition MR did not experience the reduction in BW expressed in the study of Sweeney et al. (2010), with calves weaned abruptly, or the reduced ADG shown in the study of Cowles et al. (2006), where calves were fed over 1,300 g of MR powder preweaning, during the immediate postweaning phase. This was likely due to a combination of gradual weaning and consumption of about $200 \mathrm{~g}$ less MR powder. If calves were fed more MR, visitation may have proven to be beneficial in reducing stress and improving performance during weaning.

Over the entire study, calves that were fed A0 and A1 during the preweaning phase were taller had greater girth and weighed more than the calves formerly fed $\mathrm{C} 0$ and $\mathrm{C} 1$ treatments. Following these calves for a longer period postweaning is warranted to determine if the growth advantage continued.

On the day before weaning, glucose and NEFA concentrations were higher in visited calves. If visitation was hypothesized to stimulate starter intake, glucose concentrations would have been expected to be lower in visited calves, which was not the case in our experi- 
ment. During the weaning week, an interaction for glucose concentration was observed, with A1 calves having the highest glucose concentrations whereas calves on the A0 treatment having the lowest glucose concentrations. Again, this does not support our contention that visiting calves would stimulate starter intake resulting in reduced blood glucose concentrations as the calf transitions from a preruminant to a ruminant.

Concentrations of NEFA were similar between treatments. These results do not concur with those of Kmicikewycz et al. (2013), who observed higher NEFA concentrations in calves fed higher protein MR; however, they did not measure NEFA during the weaning week. Nonesterified fatty acids can be derived from dietary or adipose sources. In the current study, NEFA were only measured immediate pre- and postweaning, as well as during the weaning week. Possibly the act of visitation could have resulted in a stress and stimulate lipolysis on the last day of the preweaning period $(\mathrm{d}$ 41); however, only one sample was taken preweaning. Cortisol concentrations tended to be higher during the weaning week for visited calves. This could be due to the visitor taking a blood sample causing a stress in the calf. Terre et al. (2006a) observed no difference in serum cortisol concentration of calves that were individually or group housed and fed an enhanced milk replacer feeding regimen. Likewise, Sutherland et al. (2014) observed no differences in serum cortisol in calves up to 6 wk of age with different bedding types or space allocations. In 7-mo-old beef heifers, Hickey et al. (2003) either weaned calves abruptly weaned or did not wean and blood samples were taken beginning $168 \mathrm{~h}$ before weaning and at 24,48 , and $168 \mathrm{~h}$ after weaning. Those authors found no effect of weaning on plasma cortisol, but the effect of sampling increased cortisol concentration regardless of treatment. These data indicate that the act of sampling results in an increase in cortisol concentrations supporting our results. Immediately postweaning, blood glucose concentrations were reduced in calves formerly fed the higher plane of nutrition MR (A0, A1) whereas urea tended to be higher in these calves, possibly suggesting that these calves are transitioning to a ruminant. Concomitantly, these calves tended to have elevated cortisol concentrations indicating that they were experiencing more stress due to weaning than the conventionally fed calves.

\section{CONCLUSIONS}

Calves fed the higher plane of nutrition MR regimen experienced higher gains before weaning than conventionally fed calves. Water intake was higher during the preweaning period for the higher plane of nutrition MR calves. Immediately after weaning, blood glucose con- centrations were lower and blood urea concentrations were elevated in calves formerly fed the higher plane of nutrition MR compared with the conventionally fed calves, suggesting that these calves adjusted to the calf starter diet over the weaning phase. Possibly, repeating this experiment with more calves would show a benefit to visitation. Visitation of the calves by humans was not beneficial in improving growth and performance in this experiment.

\section{ACKNOWLEDGMENTS}

The authors thank the George Walker Milk Fund (Boston, MA) for financial support. Partial funding was provided by the New Hampshire Agricultural Experiment Station (Durham). This is Scientific Contribution Number 2603. This work was supported by the USDA National Institute of Food and Agriculture (Washington, DC; NC-2042, accession number 1001283) Project. The authors thank Land O'Lakes Animal Milk for colostrum replacer, and milk replacer and Blue Seal Feeds (Bow, NH) for calf starter.

\section{REFERENCES}

AOAC International. 1995. Official Methods of Analysis. 15th ed. AOAC International, Arlington, VA.

AOAC International. 2002. Official Methods of Analysis. 17th ed. AOAC International, Gaithersburg, MD.

Appleby, M. C., D. M. Weary, and B. Chua. 2001. Performance and feeding behaviour of calves on ad libitum milk from artificial teats. Appl. Anim. Behav. Sci. 74:191-201.

Chua, B., E. Coenen, J. van Delen, and D. M. Weary. 2002. Effects of pair versus individual housing on the behavior and performance of dairy calves. J. Dairy Sci. 85:360-364.

Cowles, K. E., R. A. White, N. L. Whitehouse, and P. S. Erickson. 2006. Growth characteristics of calves fed an intensified milk replacer regimen with additional lactoferrin. J. Dairy Sci. 89:48354845.

Davidson, J.A., B.L. Miller, H.C. Puch, T.J. Earleywine, and K.M. Daniels. 2013. Comparison of planes of nutrition on growth performance and rumen papillae development of dairy calves. J. Dairy Sci. 96(E-Suppl.):95.

De Paula Vieira, A., M. von Keyserlingk, and D. M. Weary. 2012 Presence of an older weaned companion influences feeding behavior and improves performance of dairy calves before and after weaning from milk. J. Dairy Sci. 95:3218-3224.

Hickey, M. C., M. Drennan, and B. Earley. 2003. The effect of weaning suckler calves on the plasma concentrations of cortisol, catecholamines, leukocytes, acute-phase proteins on in vitro interferongamma production. J. Anim. Sci. 81:2847-2855.

Hill, T. M., H. G. Bateman II, J. M. Aldrich, J. D. Quigley, and R. L. Schlotterbeck. 2013. Evaluation of ad libitum acidified milk replacer programs for dairy calves. J. Dairy Sci. 96:3153-3162.

Hill, T. M., H. G. Bateman II, J. M. Aldrich, and R. L. Schlotterbeck. 2010. Effect of milk replacer program on digestion of nutrients in dairy calves. J. Dairy Sci. 93:1105-1115.

Jasper, J., and D. M. Weary. 2002. Effects of ad libitum milk intake on dairy calves. J. Dairy Sci. 85:3054-3058.

Jensen, M. B., L. R. Duve, and D. M. Weary. 2015. Pair housing and enhanced milk allowance increase play behavior and improved performance in dairy calves. J. Dairy Sci. 98:2568-2575. 
Kmicikewycz, A. D., D. N. da Silva, J. G. Linn, and N. B. Litherland. 2013. Effects of milk replacer program fed 2 or 4 times daily on nutrient intake and calf growth. J. Dairy Sci. 96:1125-1134.

Lensink, B. J., X. Fernandez, X. Boivin, P. Pradel, P. Le Neindre, and I. Veissier. 2000. The impact of gentle contacts on ease of handling, welfare, and growth of calves and on quality of veal meal. J. Anim. Sci. 78:1219-1226.

NRC. 2001. Nutrient Requirements of Dairy Cattle. 7th rev. ed. Natl. Acad. Sci., Washington, DC.

Raeth-Knight, M., H. Chester-Jones, S. Hayes, J. Linn, R. Larson, D. Ziegler, B. Ziegler, and N. Broadwater. 2009. Impact of conventional or intensive milk replacer programs on Holstein heifer performance through six months of age and during first lactation. J. Dairy Sci. 92:799-809.

Soberon, F., E. Raffrenato, R. W. Everett, and M. E. Van Amburgh. 2012. Preweaning milk replacer intake and effects on long-term productivity of dairy calves. J. Dairy Sci. 95:783-793.
Sutherland, M. A., G. M. Worth, and M. Stewart. 2014. The effect of rearing substrate and space allowance on the behavior and physiology of dairy calves. J. Dairy Sci. 97:4455-4463.

Sweeney, B. C., J. Rushen, D. M. Weary, and A. M. dePassille. 2010. Duration of weaning, starter intake, and weight gain of dairy calves fed large amounts of milk. J. Dairy Sci. 93:148-152.

Terre, M., A. Bach, and M. Devant. 2006a. Performance and behavior of calves reared in groups or individually following an enhancedgrowth feeding programme. J. Dairy Res. 73:480-486.

Terre, M., M. Devant, and A. Bach. 2006b. Performance and nitrogen metabolism of calves fed conventionally or following an enhancedgrowth feeding program during the preweaning period. Livest. Sci. 105:109-119.

Terre, M., M. Devant, and A. Bach. 2007. Effect of level of milk replacer fed to Holstein calves on performance during the preweaning period and starter digestibility at weaning. Livest. Sci. 110:82-88. 